\title{
Theatrical Landscape: Intersections between the Reception of Wagner and Offenbach in Nineteenth-Century Budapest ${ }^{1}$
}

\author{
Péter Bozó \\ Institute of Musicology \\ Research Center for the Humanities \\ of the Hungarian Academy of Sciences \\ Táncsics Mihály u. 7. 1014 Budapest, Hungary \\ E-mail: bozo.peter@btk.mta.hu
}

(Received: August 2017; accepted: October 2017)

\begin{abstract}
It is strange to find Wagner and Offenbach mentioned together at the time of their reception in nineteenth-century Budapest, and measured against each other in the Hungarian press. This study seeks to interpret that juxtaposition in terms of the system of theatrical institutions in Budapest at the time. Factors identified that concern directly the way Hungarians received the two stage composers are the multinational, multicultural character of theater life, the want of distinctions between genres, and the ongoing changes in the institutional system of the theater.
\end{abstract}

Keywords: Wagner reception, Offenbach reception, theatrical landscape, Budapest

Why mention Richard Wagner and Jacques Offenbach together - one an author of musical drama of vast dimensions and the other a composer of delicate music for witty operettas? Well, the idea is not mine, insomuch as the German scholar Peter Ackermann, in the mid-1980s, dedicated a whole study to the relationship of the two composers. ${ }^{2}$ His title quotes that of a Wagner play written in 1870, at the time of the Franco-Prussian War, in which Offenbach himself appears on the scene. ${ }^{3}$ It is characteristic that the study in question was written by a German musicologist, and understandable that since World War II, the names of the two

1. This study was supported by a post-doctoral scholarship (PD 124 089) from the Hungarian National Research, Development and Innovation Office (NKFIH) and a János Bolyai Research Scholarship from the Hungarian Academy of Sciences.

2. Peter Ackermann, "Eine Kapitulation: zum Verhältnis Offenbach-Wagner," in Jacques Offenbach: Komponist und Weltbürger, hrsg. Winfried Kirsch und Ronny Dietrich (Mainz: Schott's Söhne, 1985), 135-148.

3. Richard Wagner, "Eine Kapitulation. Lustspiel in antiker Manier," in Sämtliche Schriften, Bd. 9 (Leipzig: Breitkopf und Härtel, 1912), 3-41. 
composers have been seen as antagonistic and antithetical. It is obviously difficult to disregard the fact that Offenbach's music was stigmatized under the Third Reich between 1933 and 1945 and could not be played publicly, ${ }^{4}$ while the performances of Wagner's works were employed as vehicles for propaganda. ${ }^{5}$ (It should be added that Offenbach's works underwent a similar fate in Hungary between 1939 and 1945.)

However, the antithesis between Wagner and Offenbach arose not only in twentieth-century Germany, but in nineteenth-century Hungary, if not in so extreme a way. Offenbach was in Pest in April 1872 to conduct his operetta Schneeball [Boule-de-neige] at the Gyapjú utca German Theater (Deutsches Theater in der Wollgasse), as he had done earlier in the year at the Carltheater in Vienna. ${ }^{6}$ While in Pest, he saw a performance of Wagner's Tannhäuser (or a part of one) at the National Theater (Nemzeti Színház). The event was reported by the Hungarian journal Fövárosi Lapok:

The Tannhäuser performance last Saturday was in many ways more superb than any so far. ... This time we saw the Pest haute crême in the boxes. In one ground floor box sat Offenbach, the prolific operetta composer. The butterfly visited the lion, but could not stand the lion's great voice for long: he heard only one and a half acts of Wagner's music, which marks the diametric opposite of his in the music world. ${ }^{7}$

Here the animal metaphor used by the anonymous author - for whom Offenbach was evidently a diametric opposite of Wagner - is suspiciously similar to one used by Robert Schumann, telling of a Rossini encounter with Beethoven:

Der Schmetterling flog dem Adler in den Weg, dieser wich aber aus, um ihn nicht zu zerdrücken mit dem Flügelschlag. ${ }^{8}$ [The butterfly crossed the path of

4. Stephan Stompor, "Die Offenbach-Renaissance um 1930 und die geschlossenen Vorstellungen für Juden nach 1933," in Offenbach und die Schauplätze seines Musiktheaters, hrsg. Rainer Franke (Laaber: Laaber, 1999), 257-258.

5. Brigitte Hamann, Winifred Wagner oder Hitler's Bayreuth (München: Piper, 2005).

6. On Offenbach's reception in Vienna, see Walter Obermaier, "Offenbach in Wien: Seine Werke auf den Vorstadtbühnen und ihr Einfluß auf das Volkstheater," in Offenbach und die Schauplätze, 11-30; Matthias Spohr, "Inwieweit haben Offenbachs Operetten die Wiener Operette aus der Taufe gehoben?," ibid., 31-68; Marion Linhardt, "Offenbach und die französische Operette im Spiegel der zeitgenössischen Wiener Presse," ibid., 69-84; Rainer Franke, "Chronologie der Aufführungen der Bühnenwerke Offenbachs in Wien, 1858-1900. Programme, Statistiken, Rezensionen,” ibid., 119-182.

7. “A Tannhäuser múlt szombati előadása sok tekintetben kitünőbb volt, mint az eddigiek. [...] A páholyokban együtt láttuk ezúttal Pest haute crême-jét. Egy földszinti páholyban ült Offenbach is, az operettek termékeny szerzője. A lepke meglátogatta az oroszlánt, de hatalmas hangját nem sokáig állta ki, s csak másfél felvonást hallgatott meg Wagner zenéjéböl, mely a zenevilágban csaknem ellenkező sarokpontot képez, mint az övé." N. N., "Fővárosi hírek," Fővárosi Lapok 9/92 (23 April 1872), 399.

8. Robert Schumann, Gesammelte Schriften über Musik und Musiker (Leipzig: Wigand, 1854), 210. 
the eagle, but the latter turned aside in order not to crush it with the beating of his wings. $]^{9}$

Of course, the reviewer of the Fövárosi Lapok mentions the two composers together and compares them because Offenbach was himself present at the Wagner performance. It is all the more interesting, however, that the Wagner-Offenbach antithesis also occurs without any "meeting" of this kind between them. For example, in December 1866, two weeks after the premiere of Wagner's Lohengrin at the Pest National Theater, the Hungarian music magazine Zenészeti Lapok published a review of it, whose author, in all likelihood the journal's editor, Kornél Ábrányi, compared Wagner's piece to Italian opera in general, and more surprisingly to Offenbach's operettas. He wrote, among others, the following:

Frequently, the objection to Wagner's music heard is that there are very few melodies in it, [so] it is incomprehensible, just for musicologists, and what is more for the cream of musicologists. Those who talk that way are seeking a reason without finding it. For if people hear out this opera attentively and are only to some degree musical connoisseurs, or merely have some affinity for music, they must recognize on the contrary that there are only too many melodies in Wagner, if not in the same sense as the word can be used with Italian operas or Offenbach's operettas. ${ }^{10}$

It is worth noting that Ábrányi was a Wagner propagandist, and from his few sentences it is clear that he sought to render Wagner's music understandable and acceptable to Pest audiences of the time. ${ }^{11}$ Yet the paragraph reveals something not only of Ábrányi's relation to Wagner, but of the place Offenbach held in the system of values at the time. To Ábrányi, Offenbach's music marks the diametric opposite of Wagner's, but stands concurrently on the same level as Italian opera.

Ábrányi's equation of Offenbach's operettas and Italian operas surprises today's musicologists, as post-Offenbach operetta in twentieth-century Habsburg and post-Habsburg Hungary, moved in a commercially popular direction. Thus

9. Robert Schumann, On Music and Musicians, ed. Konrad Wolff, transl. Paul Rosenfeld (Berkeley-Los Angeles: University of California Press, 1983), 235.

10. "Sokszor lehet azt az ellenvetést hallani Wagner zenéje ellen, hogy kevés benne a melódia, érthetetlen, csak a zenetudósoknak való, s még ezekből is a javának. Akik így beszélnek, azok keresik az okot anélkül, hogy megtalálnák. Mert aki csak egyszer is figyelemmel végighallgatja a dalművet, s hozzá egy keveset zeneértő vagy ehhez fogékonysággal bír, be kell ismernie, hogy ellenkezőleg[,] nagyon is sok benne a melódia, már t[udni]i[1lik] nem abban az értelemben, amint ezt a szót az olasz operákra vagy Offenbach operettjeire lehet alkalmazni." "ák” [Kornél Ábrányi], "Lohengrin. Regényes dalmü 3 felvonásban[,] szövegét s zenéjét írta: Wagner Richárd," Zenészeti Lapok 7/11 (16 December 1866), 164.

11. For Ábrányi's role in the Hungarian reception of Wagner, see Emil Haraszti, Wagner Richard és Magyarország (Budapest: MTA, 1916), 230-232. See also Ildikó Varga, Richard Wagner, Hungary, and the Nineteenth Century. Aspects of the Reception of Wagner's Operas and Music-Dramas (PhD Diss., Graz: Universität für Musik und Dramatische Kunst, 2014). 
the term "operetta" today no longer means a sub-genre of opera, but a separate genre distinct from opera, but in the mid-nineteenth century, particularly before the European dissemination of Offenbach's works, operetta was seen as such a sub-genre: musical stage work in which spoken dialogue replaced recitative. The very term for it betrays that meaning, in a way well documented by Sabine Ehrmann-Herforth's "Operetta" entry in the Handwörterbuch der musikalischen Terminologie, which quotes widely from music dictionaries of the seventeenth to twentieth centuries. ${ }^{12}$

It can be objected that the two press reports quoted are just two examples taken out of context, but in fact there are further cases of the names Wagner and Offenbach being juxtaposed in music reviews of nineteenth-century Budapest. To take another example: a quarter-century after the Lohengrin premiere, in 1890, a review appeared in the music magazine Zenelap of the first performance of Offenbach's one-act operetta Le Mariage aux lanternes at the Budapest Royal Opera House. The author, who may have been István Kereszty, had heavy criticism for the Royal Opera House, particularly the programming of Gustav Mahler, who was music director at the time:

It is nice of him [i. e. Mahler] to introduce every sub-genre of opera into our Opera House - as we have only one Opera House, and so cannot separate the different operatic genres. But he should not go so far as to introduce Offenbach's operettas into the home of the serious Muse, as it is rumored. We salute Wagner's music with holy horror and listen to it, just not too much, and we also would like to hear Kreutzer's poetic and heartbreaking songs, the witty and fresh music of a Frenchman, and the Hungarian character of our Royal Opera House should be conserved through the cultivation of the works by Hungarian composers. $^{13}$

In contrast to Ábrányi's review, Offenbach and Wagner are mentioned here as two composers falling into one category, neither being too desirable on the Opera House stage. Wagner's music is graded somewhat better and could be allowed, if not too often and if saluted "with holy horror," but performing Offenbach there is condemned out of hand. Yet the strongest remark in the quotation is its last

12. Sabine Ehrmann-Herfort, "Operette”, in Handwörterbuch der musikalischen Terminologie, hrsg. Albrecht Riethmüller, Bd. IV (Stuttgart: Steiner, 1972), 1-20.

13. "Szép dolog tőle, hogy ő az operák minden müfaját igyekszik operánkban meghonosítani, - mert nekünk csak egy dalszínházunk van, tehát az opera válfajokat el nem különíthetjük, de már odáig ne vigye - mint hírlett - hogy Offenbach operettjeit is bevigye a komolyabb múzsa hajlékába. - Szent borzalommal emelünk kalapot és hallgatjuk meg Wagner elementáris zenéjét, csak ne legyen túl sok eme jóból, s hallhassuk mellette Kreutzer poétikus és szivhez szóló dalait, a francia üde, szellemes és friss zenéjét, s a magyar zeneszerzők müveinek fenntartásával kell műintézetünknek ama jellegét megőrizni, hogy az Magyar Kir[ályi] Operaház." N. N., "A m[agyar] kir[ályi] operaház, a magyar opera és még egyéb," Zenelap 5/3 (30 January 1890), 2. 
sentence, and the national bias is still more emphatic because the complete review begins, "One and a half years went by and no Hungarian opera was played at the Royal Hungarian Opera House."14 That, by the way, is untrue: to quote one example, Erkel's opera György Brankovics was revived there in February 1890. Under the circumstances, it is clear that the Zenelap review was biased against Mahler, and in that context it is unsurprising that the two foreign composers programmed by Mahler, Wagner and Offenbach, should be condemned equally. More surprising is that Conradin Kreutzer, a minor German composer whose romantic opera Das Nachtlager in Granada was premiered in Budapest under Mahler's directorship, is given a positive note. (Even so, the reviewer may have been confusing him with the French Rodolphe Kreutzer, which would explain his remark about the "witty and fresh music of a Frenchman".)

So why are these music reviews being quoted? How do they concern relations between Offenbach's reception and the theatrical landscape? In my view, the aesthetic conclusions of critics and of audience members are not unconnected with the kind of institutions in which a composer is performed. So let me try to sketch here the Budapest theatrical landscape and interpret the reviews quoted in the light of changes in that landscape, as pointing to why Wagner and Offenbach would be mentioned together and measured against each other.

Even the author of the Zenelap review felt his aesthetic judgments were not uninfluenced by the institutional background, as he himself noted: "We have only one Opera House, and so cannot separate the different operatic genres." This was a tender spot in nineteenth-century Budapest music and theater. At the time of the Lohengrin premiere in 1866, the theatrical landscape of Buda and Pest was organized by language of performance, not by genre. Both cities were multi-ethnic and both had more native German speakers than Hungarian. So unsurprisingly, there were more German theaters than Hungarian ones in the mid-century. Around 1860, German performances took place in three venues: the Pest Municipal Theater (Pester Stadttheater), the Buda Castle Theatre (called Ofner Stadttheater at that time), and the Buda Summer Theater - designated as Arena in der Christinenstadt in the German-language press..$^{15}$ The number rose to four in 1860, when the Viennese entrepreneur Karl Alsdorf opened the Thalia Theater in Pest City Park, which played until 1864. By contrast, there was only one theater for Hungarian performances up to 1861: the Pest National Theater (Nemzeti Színház), which differed from German theaters in being subsidized by the state. ${ }^{16}$ For a short while, the number of Hungarian theaters also rose by one, when György

14. „Másfél éve elmúlt, hogy a M[agyar] K[irályi] Operaházban magyar opera elő nem adatott.” Ibid., 1.

15. For the history of German-speaking theater in Budapest, see Wolfgang Binal, Deutschsprachiges Theater in Budapest (Wien-Köln-Graz: Böhlaus Nachfolger, 1972).

16. For the history of the Pest National Theater, see Pukánszkyné Jolán Kádár, A Nemzeti Színház százéves története (Budapest: Magyar Történelmi Társulat, 1940). 
Molnár, director of an itinerant troupe active in the Hungarian provinces, opened a Buda Folk Theater (Budai Népszínház), where the repertoire was lighter entertainment and many operettas by Offenbach and others were performed. This, however, was short-lived, as it went into bankruptcy in 1864 and again, finally, in 1870. ${ }^{17}$ Neither Buda nor Pest had a court opera at the time. The National Theater and German theaters were of the multi-purpose type known as Mehrspartentheat$e r$, offering opera, prose drama, and light entertainment.

Those were the conditions under which the first Offenbach and Wagner performances in Hungarian took place at the same institution, the National Theater. Cultivation of both had begun somewhat earlier in the German theaters: Offenbach's one-acters first appeared in the summer of 1859, when Carl Treumann, an actor and stage director at the Vienna Carltheater, gave guest performances at the Buda Summer Theater. ${ }^{18}$ The first Budapest Wagner premiere was Tannhäuser at the Pest Municipal Theater on 6 March 1862. However, the first Offenbach and Wagner performances in Hungarian took place at the National, and interestingly, some singers took leading roles in works by both. For example, the soprano Ilka Markovits sang Elisabeth in the first Hungarian Tannhäuser, conducted by Hans Richter, and also created Catherine in Offenbach's Le Mariage aux lanternes, Susanne in Un Mari à la porte, Antoine in Le Violoneux, Manuelita in Pépito, and Valentin in La Chanson de Fortunio. Likewise, the bass Károly Köszeghy sang Heinrich der Vogler in Lohengrin, Daland in The Flying Dutchman, and Cecco in Rienzi, while creating Martel in Offenbach's Un Mari à la porte, Vertigo in Pépito and Dig-dig in La Chatte métamorphosée en femme (Table 1).

What is more, both Offenbach's company and Wagner appeared at the National Theater within a short period: the Théâtre des Bouffes-Parisiens came to Pest in summer 1861 for a six-day visit (playing mostly operettas by Offenbach, Table 2, see also Plate 1), while Wagner conducted a selection of his operas in July 1863 (Table 3, see also Plate 2). So it is no surprise to hear Offenbach described some years later as Wagner's antithesis, in Ábrányi's review of the Lohengrin premiere.

By the mid-1880s, marked change in the Budapest theatrical landscape had made an impact on the reception of both composers. In 1870, the Pest German Theater closed down and German performances in Buda were prohibited by the authorities: the Buda Summer Theater and the Castle Theater became Hungarian theaters. ${ }^{19}$ Yet for a long time, it remained a problem for Hungarian theaters to

17. For the history and repertoire of the Buda Folk Theater, see Pukánszkyné Jolán Kádár, A Budai Népszínház története (Budapest: Magyar Színházi Intézet, 1979) and Mályuszné Edit Császár, A Budai Népszínház müsora. Adattár (Budapest: Színháztudományi és Filmtudományi Intézet, 1957).

18. The first pieces by Offenbach played in the Buda Summer Theater were Hochzeit bei Laternenschein (Le Mariage aux lanternes, first perf. on 24 May 1859), Das Mädchen von Elisonzo (Pépito, first perf. on 31 May 1859) and Die Zaubergeige (Le Violoneux, first perf. on 8 June 1859). See Pester Lloyd 6/125 (27. Mai 1859, Morgenblatt), [3].; 6/130 (1. Juni 1859, Morgenblatt), [3].; 10/130 (8. Juni 1859, Morgenblatt), [5].

19. For the repertoire of the Buda Summer Theater, see Lajos Koch, A budai Nyári Színkör (Adattár) (Budapest: Színháztudományi Intézet/Országos Színháztörténeti Múzeum, 1966). 
TABLE 1 The Offenbach and Wagner roles of Ilka Markovits and Károly Köszeghy in the premieres at the Pest National Theater

\begin{tabular}{|c|c|c|c|}
\hline Premiere & Piece & $\begin{array}{l}\text { Ilka Markovits } \\
\text { (1839-1915) }\end{array}$ & \begin{tabular}{|l|} 
Károly \\
Köszeghy \\
1820-1891)
\end{tabular} \\
\hline 21 Nov 1860 & $\begin{array}{l}\text { Offenbach: Eljegyzés lámpafénynél } \\
\text { [Le Mariage aux lanternes] }\end{array}$ & $\begin{array}{l}\text { Katalin } \\
\text { [Catherine] }\end{array}$ & \\
\hline 12 Feb 1861 & $\begin{array}{l}\text { Offenbach: Férj az ajtó elött } \\
\text { [Un Mari à la porte] }\end{array}$ & $\begin{array}{l}\text { Zsuzsanna } \\
\text { [Suzanne] }\end{array}$ & $\begin{array}{l}\text { Trompeur Márton } \\
\text { [Martel] }\end{array}$ \\
\hline 14 March 1861 & $\begin{array}{l}\text { Offenbach: A varázshegedü } \\
{[\text { Le Violoneux }]}\end{array}$ & Antal [Antoine] & \\
\hline 30 Sept 1861 & Offnebach: Az elizondói leány [Pépito] & Manuelita & Vertigo \\
\hline 25 Jan 1862 & $\begin{array}{l}\text { Offenbach: Fortunio dala } \\
\text { [La Chanson de Fortunio] }\end{array}$ & Bálint [Valentin] & \\
\hline 31 Jul 1862 & $\begin{array}{l}\text { Offenbach: Denis úr és neje } \\
{[\text { M. et Mme Denis }]}\end{array}$ & Nanette & \\
\hline 12 Oct 1863 & $\begin{array}{l}\text { Offenbach: Az átváltozott macska } \\
\text { [La Chatte métamorphosée en femme] }\end{array}$ & & Dig-Dig \\
\hline 1 Nov 1866 & Wagner: Lohengrin & & $\begin{array}{l}\text { Madarász Henrik } \\
\text { [Heinrich der } \\
\text { Vogler }] \\
\end{array}$ \\
\hline 11 March 1871 & Wagner: Tannhäuser & $\begin{array}{l}\text { Erzsébet } \\
\text { [Elisabeth] }\end{array}$ & \\
\hline 10 May 1873 & $\begin{array}{l}\text { Wagner: A bolygó hollandi } \\
\text { [Der fliegende Holländer] }\end{array}$ & & Daland \\
\hline 24 Nov 1874 & Wagner: Rienzi & & Cecco \\
\hline
\end{tabular}

attract a mostly German-speaking theater-going public. Although a new German theater opened in 1869 in Pest's Gyapjú utca, this Deutsches Theater in der Wollgasse was to be the last German theater in the capital and burnt down in 1889 . It should be noted that the first Budapest performance of Wagner's Der Ring des Nibelungen took place in this theater on 23-26 May 1883 when Angelo Neumann's travelling company gave a guest performance. As for the Hungarian venues, there was an attempt to fill in for the defunct Buda Folk Theater: a short-lived popular house called the István-téri Theater, built by Gyula Miklósy in Pest's István tér, which functioned from 1872 to 1874 , and a summer theater called the Miklósy Színkör. ${ }^{20}$ In 1875, the genres of theatrical entertainment - folk plays and operetta - moved from the National Theater to the newly opened Folk Theater (Népszínház) in Pest. ${ }^{21}$ In 1884, the Royal Opera House opened, so that opera

20. For the history and repertoire of Miklósy's theaters, see Ágnes Alpár, Az István-téri Színház, 18721874 (Budapest: Magyar Színházi Intézet, 1986).

21. For the repertoire of the institution, see Berczeli Anzelm Károlyné, A Népszínház müsora. (Adattár) (Budapest: Színháztudományi és Filmtudományi Intézet/Országos Színháztörténeti Múzeum, 1957). 
Plate 1 One of the theatre playbills of the Pest guest performances of the Théâtre des Bouffes-Parisiens

(From the Theater History Collection of the Széchényi National Library, Budapest)

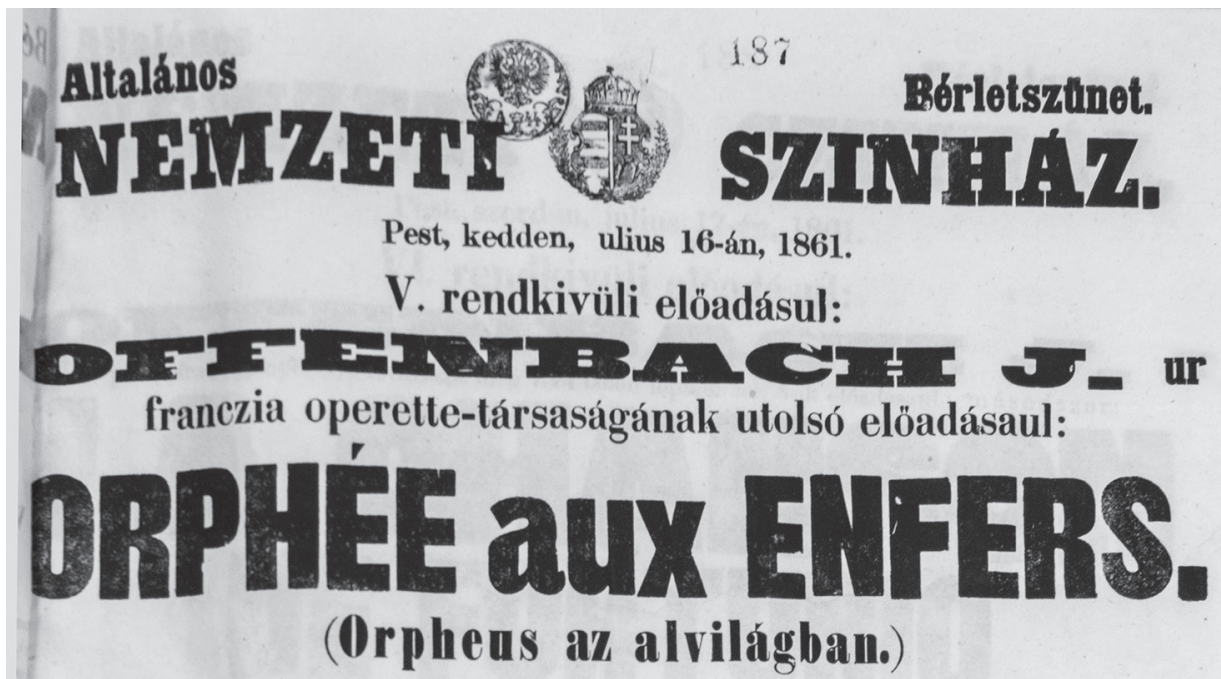

Opéra bouffon en deux actes et quatre tableaux de Mr. Hector Crémieux. Musique de Mr. J. Offenbach.

1. tableau: Ia mort d'Eurydice. 2. tab- 3. tableau: Le Boudoir de Pluton. 4. tableau: L'Olympe. leau: Les Fnfers:

\section{P E R S O N N A GE:}

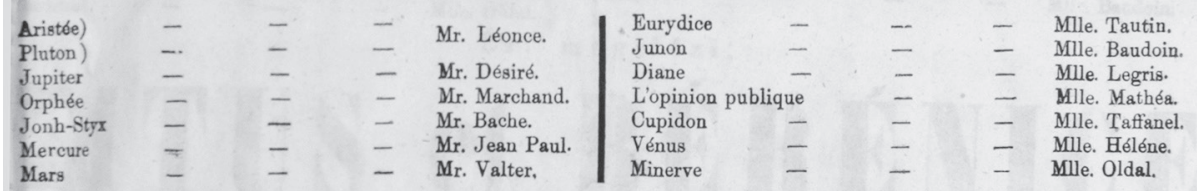

Au 4-émie tableau:

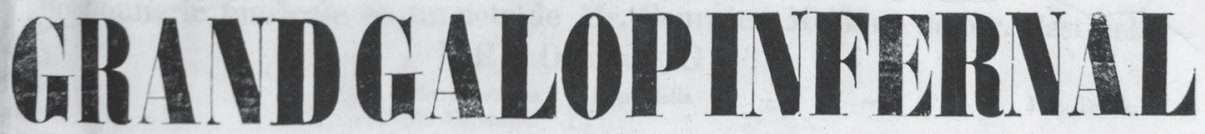

Dansé par tous les artistes et le corps de ballet.

Karmester: VARNEY.

A fölemelt helyárak következők lesznek ;

Foldrunti, nagy elå emeleti páholy $10 \mathrm{ft}$. Másodemeleti páholy 8 it. Erkélyszék $3 \mathrm{ft}$. Forldszinti zártszék $1 \mathrm{ft} .80 \mathrm{kr}$. Fơldszinti bemenet $1 \mathrm{ft}$. Gyermekieg folderintre $50 \mathrm{kr}$. Másodemeleti zártszék $1 \mathrm{ft}$. $20 \mathrm{kr}$. Masodemeleti bemen. $60 \mathrm{kr}$. Gyermekjegy második emeletre 30 . kr. Karrati bemen. $30 \mathrm{kr}$. Kz azon 12 rendkivüli elóadas ótōdike, melyeket a bérlethirdetményben az igazgatóság különösen kikötött, melylyek alkalmával a t. bérló uraságok kivétel nélkül, tehát azok is, kik páholyaikat a bérletszünetes elóadásokhoz lyek alkalmával a t. bérlót helyeiket csupán a napi helyárak lefizetése mellett használhatják, mire nézvo ma d. e. 10 oráig méltóztassanak rendelkezni; azontul mások kivánata fogván figyelembe vétetni.

rece Ma, szabadjegyek nem használhatók

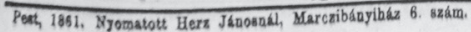

Kiadta : Caepregi, titkar. 
Plate 2 The theatre playbill of Wagner's first concert in the Pest National Theater

(From the Theater History Collection of the Széchényi National Library, Budapest)

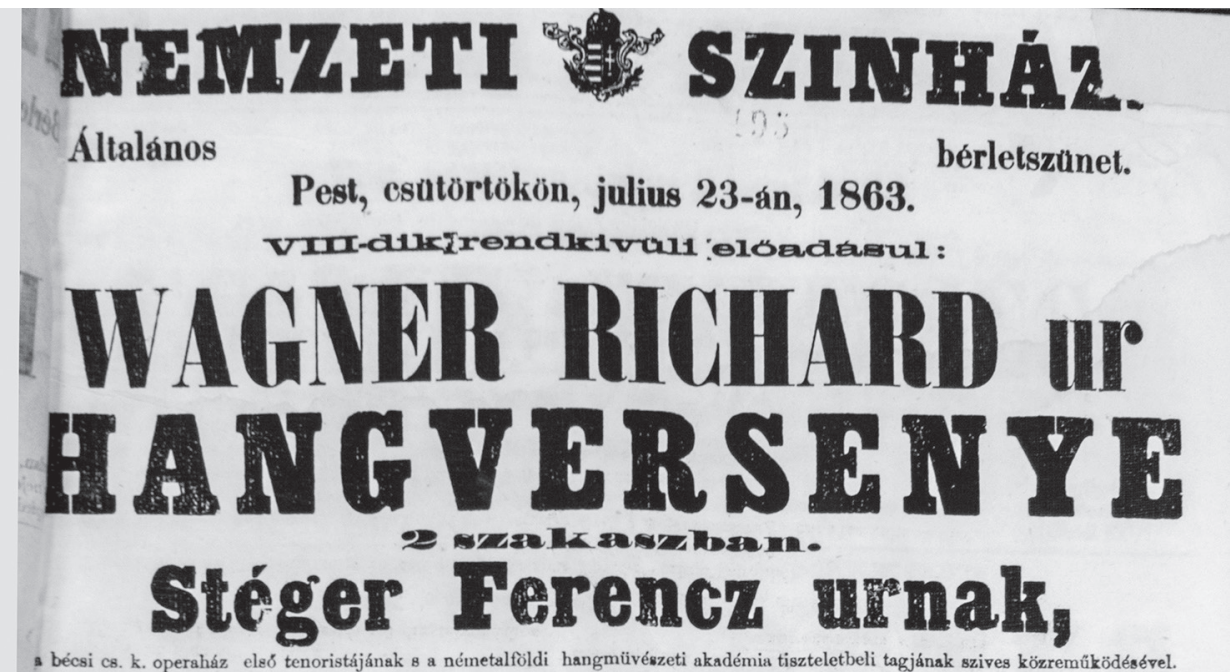

A tetemesen megerösitelt zenekart WAGNER RICHARD ur vezérlendi.

uinden e hangversenyben előadand 6 żnemŭ

\section{DET}

1. Nyitány "Tannhüuserce czimü operából ; elóadja a nemzeti szinház megerösitett zenelsara.

2. a) "Flsa" beszélgetése a szellbkkel" \}, „Lohengrin" czimü dalmüböl; énekli

b) "Ortrud megintése"

3. „A szent Graal“ Elôjáték.

4. "Menyegzöi zene" Bevesetés \& 3-dik felvonáshoz "Lohengrin" cxinü dalmüból; elóadja a nemzeti szinház

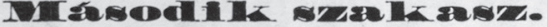

5. Elöjáték, és az utolsó felvonás végzete \},Tristán és Isolde“ czimü dalmübol ;

(Szerelmi dal és megdicsơưlés.) ( elóadja a megerősitett zenekar.

6. a) ,A mesterdalnok-czéh gyullekezete" a zenekar által. | A "Norinbergi mesterdalnokok"

b) „Pogner mester felszóllalása“" énekli Köszeghi.

7. „Zsigmond szerelmi dala." Énekli Simon. ( A "Walkür“ czimü dalmübôl,

8. "A Walktirök lovaglása"

teljes zenekarra.

9. "Kovács-dalok" Snigfrid crimü operából.

a) "Olvasztó-dal“" '́nekli Stéger Ferencz ur.

STÉGER FERENCZ ur, a hangversenyzö iránti szivességböl lép föl.

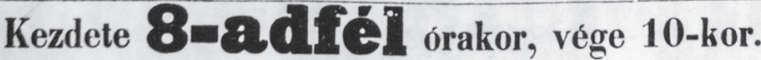

Joknainé, Prielle Cornelia, Felekiné M. Flóra, Hamvai Kovács Imréné, Bognár Vilma B.-né, Láng Paulina, Pauliné, Hubenainé, Pauli, Tơth József, Szigeti, Feleki szabadságidejuiket használják. Szzilágyiné beteg.

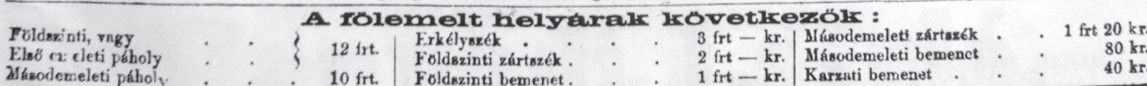

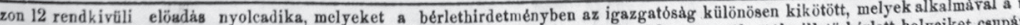
bérlỏ uraságok kivétel nélküli, tehát azok is. kik páholyaikat a bérletszünetes elöadásokhoz megváltották, illetô bérlett helyeiket csupán a napi helyárak lefizetése mellett használhatjak, mire nézve ma d. e. 10 óráig méltóztassanak rendelkezni; azontul masok kirànał fogvàn figyelembe vétetni.

A ki nem bérelt páholy - és zártszékek iránt Wagner Richard ur második hangversenyére rendelkezhetni naponkit $9-1$ óraközt.

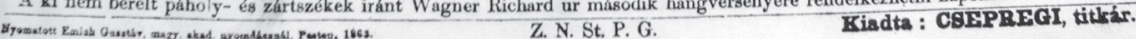


TABLE 2 Guest performances of the Théâtre des Bouffes-Parisiens at the Pest National Theater, 1861

\begin{tabular}{|l|l|}
\hline Date & Piece \\
\hline 12 July 1861 & $\begin{array}{l}\text { Offenbach: La Chatte métamorphosée en femme } \\
\text { Offenbach: Mesdames de la Halle }\end{array}$ \\
\hline 13 July 1861 & $\begin{array}{l}\text { Offenbach: La Chanson de Fortunio } \\
\text { Offenbach: Une Demoiselle en lôterie }\end{array}$ \\
\hline 14 July 1861 & $\begin{array}{l}\text { Varney: La Polka des sabots } \\
\text { Offenbach: Un Mari à la porte }\end{array}$ \\
\hline 16 July 1861 & Offenbach: Orphée aux enfers \\
\hline 17 July 1861 & $\begin{array}{l}\text { Offenbach: La Chanson de Fortunio } \\
\text { Gastinel, Titus et Bérénice }\end{array}$ \\
\hline 18 July 1861 & Offenbach: Le Pont des soupirs \\
\hline
\end{tabular}

TABLE 3 Wagner's appearances at the Pest National Theater, 1863

\begin{tabular}{|l|l|}
\hline Date & Piece \\
\hline 23 July 1863 \\
(conducted by & Tannhäuser overture \\
Wagner) & Elza's Song to the Breezes and Ortrud's Admonition from Lohengrin \\
& Prelude and Wedding March from Lohengrin \\
Prelude and Isolde's Love Death from Tristan und Isolde \\
Entrance of the Guilds and Pogner's Speech from Die Meistersinger von \\
Nürnberg \\
Siegmund's Love Song and the Ride of the Valkyries from Die Walküre \\
Siegfried's Forging Songs from Siegfried
\end{tabular}

need no longer be played in the National Theater. ${ }^{22}$ Incidentally, the Opera House was built on the site of an earlier German institution, the Fürst-Theater.

So Budapest saw a big change between the 1866 Ábrányi's Lohengrin review and the 1890 Mahler attack in Zenelap. The institutional system seems none too favorable to Offenbach, as Budapest had no venue to match Offenbach's Paris

22. For the history of the Royal Opera House, see Géza Staud (ed.), A budapesti Operaház 100 éve (Budapest: Zenemükiadó, 1984). 
operetta theater. ${ }^{23}$ Pieces styled operetta shared a venue with a more rustic genre, the népszinmü or folk play, a local counterpart of Vienna's Volksstück. I suppose that is why the 1890 critic said, Mahler "should not go so far as to introduce Offenbach's operettas into the home of the serious Muse." This may have been a common view, explaining why his posthumous Contes d'Hoffmann was first performed in Budapest as an operetta, not an opera. I say "first," although Offenbach's opera had at least three first performances in Budapest. The very first was on 14 April 1882 at the Folk Theater, with spoken dialogue and no Giulietta act. Early next year, a more complete, five-act version was staged there. ${ }^{24}$ Yet, despite Mahler's plans to mount it at the Royal Opera House in $1890,{ }^{25}$ the full opera version with recitatives had to wait until 15 December 1900.

To sum up, there were peculiarities in the Budapest theatrical landscape and some changes not without impact on Wagner's and Offenbach's reception in the city. In my view, the reviews quoted here should be seen in the context of those nineteenth-century conditions and the changes in them.

23. On the beginnings of Offenbach's theatrical venue, see Jean-Claude Yon, "La Création du Théâtre des Bouffes-Parisiens (1855-1862), ou la difficile naissance de l'opérette," Revue d'Histoire moderne et contemporaine 39 (octobre-décembre 1992), 575-600, later forming a chapter in his book-length monograph: Jacques Offenbach (Paris: Gallimard, 22010 [12000]), 128-165. See also Matthias Brzoska, "Jacques Offenbach und die Operngattungen seiner Zeit," in Jacques Offenbach und seine Zeit, hrsg. Elisabeth Schmierer (Laaber: Laaber, 2009), 27-36.

24. On 12 January 1883.

25. As the Opera House Intendant, Ferenc Beniczky, stated in the press after his dismissal, Offenbach's opera was ready for performance when the leading soprano Bianca Bianchi (Bertha Schwartz) fell ill, and the premiere was postponed. See Beniczky Ferenc, [untitled], Budapesti Hirlap 11/25 (25 January 1891), 9. In the end, the premiere was cancelled when Mahler resigned from his post in March 1891. 
